\title{
ANALISA PROFIT DAN LOSS PADA SISTEM MANAJEMEN ASET DENGAN MENGGUNAKAN ALGORITMA MULTIPLE LINEAR REGRESSION
}

\author{
Syafrial Fachri Pane ${ }^{1}$, Chandra Kirana Poetra ${ }^{2}$, Rd. Nuraini Siti Fatonah ${ }^{3}$ \\ 1,2,3 Teknik Informatika, Politeknik Pos Indonesia
}

\section{Article Info:}

Dikirim: 02 Februari 2021

Direvisi: 24 Juni 2021

Diterima: 29 Juni 2021

Tersedia Online: 30 Juni 2021

Penulis Korespondensi:

Syafrial Fachri Pane

Politeknik Pos Indonesia, Bandung, Indonesia

Email:

syafrial.fachri@poltekpos.ac.id

\begin{abstract}
Abstrak: Analisa profit dan loss merupakan hal yang dibutuhkan oleh setiap perusahaan dalam menjalankan bisnis yang dijalankannya. Tanpa adanya proses analisa, perusahaan tidak akan bisa memprediksi berapa keuntungan yang didapat. Oleh karena itulah dibuat suatu sistem analisa profit dan loss pada aset yang dimiliki oleh perusahaan yang nantinya akan memberikan gambaran berupa proyeksi keuntungan pada perusahaan Proses analisa profit ini dilakukan dengan menggunakan data laporan penjualan tahunan dari perusahaan yang nantinya akan di proses dengan metode multiple linear regression. Metode multiple linear regression ini merupakan metode yang sudah teruji dan sering dipakai untuk menganalisis data yang memiliki hubungan satu sama lain.Dalam penerapan metode multiple linear regression, berdasarkan data penjualan perusahaan yang digunakan, dapat disimpulkan bahwa penjualan perusahaan akan untung sebesar 2025.628 atau apabila dibilangkan menjadi dua milliar dua puluh lima juta enam ratus dua puluh delapan ribu rupiah apabila perusahaan mampu memproduksi $\left(X_{l}\right)$ barang dalam jumlah dua puluh lima ton dan menjual barang itu tiap ton nya dalam harga $\left(X_{2}\right)$ tiga puluh juta.
\end{abstract}

Kata kunci: multiple linear regression; analisa; codeigniter.

\begin{abstract}
Profit and loss analysis is an important thing that every company needed to run it's business. Without analysis, company won't be able to predict profit. That is why the writer created a profit and loss analysis system for company asset which will give the company a projection for future profit. Profit analysis is done using annual sales report from the company, which will be analyzed using a method called multiple linear regression. This multiple linear regression method is a tested method and also common methodology used to analyzed data which has a relationship to each other. In the application of multiple linear regression, based on sales data acquired from the company, it can be concluded that the company will gain 2025.628 or two billion twentyfive million six hundred twenty-eight thousand rupiah if the company able to produce $\left(X_{1}\right)$ twentyfive million tonne of goods and also if the company able to sell that goods with thirty million per tonne on price.
\end{abstract}

Keywords: multiple linear regression; analysis; codeigniter. 


\section{PENDAHULUAN}

Aset merupakan sesuatu yang mempunyai nilai dan biasanya dikelola oleh suatu industri atau organisasi atau juga perseorangan. Barang atau aset tersebut tentunya memiliki nilai tukar. Modal atau kekayaan juga dapat dijadikan sebagai pengertian dari aset [1]. Atau aset juga bisa diartikan dalam suatu hal yang perusahaan kelola, yang dijadikan sebagai sumber pendapatan, yang diharapkan akan menjadi sumber penghasilan bagi perusahaan pada masa depan baik secara langsung maupun tidak langsung[2]. Aset biasanya didapatkan atau juga diperoleh melalui proses-proses seperti pembelian, hibah, dan juga bantuan dari pihak lain. Aset juga termasuk benda yang tidak bergerak seperti sebidang tanah atau bangunan dan juga benda yang bergerak seperti kendaraan. Aset juga dapat dibagi menjadi aset berwujud, seperti bangunan, dan aset tak berwujud, seperti paten dan hak cipta[3].

Permasalahan yang telah terindentifikasi adalah kebutuhan perusahaan untuk memiliki suatu sistem yang dapat melakukan analisis serta memprediksi profit dan juga loss terhadap aset-aset perusahaan yang dimiliki. Kemampuan untuk memprediksi sendiri merupakan kemampuan yang sangat penting karena memprediksi dapat memberikan suatu landasan atau dasar untuk proses pembuatan keputusan[4].

Dari permasalahan yang telah di paparkan, perusahaan membutuhkan suatu sistem yang dapat memprediksi serta menganalisa profit dan loss dari aset yang dimiliki. Metode yang akan digunakan untuk melakukan analisis profit dan loss itu sendiri adalah metode Multiple Linear Regression. Multiple Linear Regression ini merupakan suatu bentuk penyempurnaan atau versi yang lebih kompleks dari Simple Linear Regression. Metode ini adalah suatu teknik pada bidang statistika yang menggunakan beberapa variable explanatory yang nantinya akan digunakan untuk memprediksi keluaran dalam bentuk response variable [5]. Tujuan dari penggunaan metode ini yaitu membuat perhitungan yang dapat menjelaskan kaitan dari dua, tiga atau lebih variable dan juga response variable dengan cara memasukan perhitungan linear pada data yang akan teliti. Multiple Linear Regression bisa digunakan untuk mengindentifikasi tingkat kekuatan dari suatu efek pada suatu variable yang memiliki dependensi terhadap variable lain [6].

Disini, data yang akan diteliti adalah data finansial tentang berbagai macam aset-aset yang dimiliki oleh perusahaan. Data ini akan dianalisa untuk dicari hubungan keterkaitan satu sama lain untuk nantinya digunakan dalam memprediksi pendapatan dan juga untuk menentukan apakah suatu aset itu sedang profit atau loss [7]. Cara kerja metode ini sendiri adalah dengan menentukan apa yang akan di prediksi terdahulu dalam hal ini adalah profit. Profit ini dalam hal lain adalah dependent variable. Setelah itu kita perlu mencari hubungan antara profit dengan sesuatu yang akan kita gunakan sebagai predictors atau juga variable-variable lainnya seperti misalkan berapa banyak biaya yang dikeluarkan oleh perusahaan untuk bidang-bidang atau divisi yang ada seperti penelitian dan pengembangan, biaya administrasi perusahaan, biaya pemasaran, dan biaya-biaya lainnya. Predictors inilah yang akan kita cari keterkaitannya dengan dependent variable kita yaitu profit. Setelah data-data itu semua telah didapatkan, maka Multiple Linear Regression dapat diterapkan dan dapat kita lihat seberapa besar pengaruh dari setiap variable-variable predictors yang telah kita masukan dalam perhitungan, dan apabila nilai-nilai dari variable predictors itu melebihi atau bisa juga kurang dari nilai $\mathrm{P}$ value yang telah kita tentukan sebelumnya, disaat inilah kita bisa mengetahui tentang divisi-divisi mana saja yang memiliki efek yang minimum dan juga signifikan terhadap pendapatan atau profit perusahaaan [8].

Berdasarkan dengan apa yang telah diuraikan sebelumnya, dengan adanya sistem yang akan menggunakan metode Multiple Linear Regression untuk analisa profit dan juga loss. Perusahaan dapat melihat hubungan pendapatan perusahaan dengan kriteria-kriteria lainnya seperti yang telah dijelaskan sebelumnya [9]. Dengan adanya analisi yang dilakukan oleh sistem, diharapkan perusahaan dapat membuat keputusan yang lebih tepat dalam menentukan kebutuhan finansial perusahaan.

\section{METODOLOGI PENELITIAN}

Bagian Metodologi Penelitian akan menjelaskan dan memberikan gambaran perihal penggunaan metode regresi berganda dari penjelasan awal seperti bentuk rumusnya itu sendiri sampai penggunaan metode serta penggunaan rumusnya itu sendiri sehingga menghasilkan keluaran yang sesuai seperti tujuan penelitan.

\subsection{Multiple Linear Regression}

Multiple Linear Regression adalah persamaan regresi yang melibatkan dua variabel atau lebih dalam analisisnya. Tujuannya adalah untuk menghitung estimasi parameter untuk melihat apakah variabel independen dapat menjelaskan hasil dari variabel dependen dan juga dampaknya [10]. Berikut ini adalah bentuk umum dari rumus regresi linier berganda.

$\mathrm{Y}=\alpha+\beta_{1} \mathrm{X}_{1}+\beta_{2} \mathrm{X}_{2}$

Dimana:

$$
\begin{aligned}
& \mathrm{Y}=\text { Variabel dependen (Dependent) } \\
& \mathrm{a}=\text { Variabel konstanta } \\
& \mathrm{b}=\text { Variabel koefisien regresi } \\
& \mathrm{X}=\text { Variabel independen (Independent)[7] }
\end{aligned}
$$




\section{HASIL DAN PEMBAHASAN}

\subsection{Persiapan Dataset}

Tahap pertama dalam menerapkan metode multiple linear regression sendiri adalah dengan memasukan data dan menentukan variable bebas serta variable tidak bebas yang akan kita hitung bersumber dari data sekunder penjualan perusahaan pada tabel 1 yang dapat dilihat berikut ini.

Tabel 1. Dataset perhitungan

\begin{tabular}{cccc}
\hline No & $\boldsymbol{X}_{\boldsymbol{1}}$ Produksi (ton) & $\boldsymbol{X}_{\mathbf{2}}$ Harga(juta) per/ton & Y(Keuntungan) \\
\hline 1 & 90.513 & 17.38778652 & 1573.820721 \\
2 & 30.51 & 17.24466667 & 526.13478 \\
3 & 103.734 & 17.28047059 & 1792.572336 \\
4 & 56.952 & 17.33714286 & 987.38496 \\
5 & 42.714 & 17.05066667 & 728.302176 \\
6 & 52.884 & 17.40038462 & 920.20194 \\
7 & 163.044 & 18.27974895 & 2980.403388 \\
8 & 178.092 & 16.67559056 & 2969.789274 \\
9 & 26.442 & 17.30061538 & 457.462872 \\
10 & 20.34 & 17.3587 & 353.075958 \\
11 & 100.8 & 15.9202 & 1604.75616 \\
12 & 52.884 & 17.08976923 & 903.775356 \\
13 & 50.85 & 17.4636 & 888.02406 \\
14 & 42.714 & 17.41585714 & 743.900922 \\
\hline
\end{tabular}

\subsection{Mencari Nilai Konstanta Dan Koefisien Regresi}

Tahap selanjutnya yang perlu dilakukan setelah menentukan variable bebas dan variable tidak bebas sendiri adalah dengan menghitung nilai konstanta dan nilai koefisien regresi yang digambarkan di tabel 2 serta tabel 3 berikut:

Tabel 2. Mencari nilai konstanta dan nilai koefisien regresi

\begin{tabular}{llclll}
\hline $\boldsymbol{N o}$ & \multicolumn{1}{c}{$\boldsymbol{X}_{\boldsymbol{I}}$} & $\boldsymbol{X}_{\boldsymbol{2}}$ & \multicolumn{1}{c}{$\boldsymbol{Y}$} & \multicolumn{1}{c}{$\boldsymbol{X}_{\boldsymbol{I}^{2}}$} & \multicolumn{1}{c}{$\boldsymbol{X}^{\boldsymbol{2}^{2}}$} \\
\hline 1 & 90.5 & 17.4 & 1573.820721 & 8192.6 & 302.3 \\
2 & 30.5 & 17.2 & 526.13478 & 930.9 & 297.4 \\
3 & 103.7 & 17.3 & 1792.572336 & 10760.7 & 298.6 \\
4 & 57.0 & 17.3 & 987.38496 & 3243.5 & 300.6 \\
5 & 42.7 & 17.1 & 728.302176 & 1824.5 & 290.7 \\
6 & 52.9 & 17.4 & 920.20194 & 2796.7 & 302.8 \\
7 & 163.0 & 18.3 & 2980.403388 & 26583.3 & 334.1 \\
8 & 178.1 & 16.7 & 2969.789274 & 31716.8 & 278.1 \\
9 & 26.4 & 17.3 & 457.462872 & 699.2 & 299.3 \\
10 & 20.3 & 17.4 & 353.075958 & 413.7 & 301.3 \\
11 & 100.8 & 15.9 & 1604.75616 & 10160.6 & 253.5 \\
12 & 52.9 & 17.1 & 903.775356 & 2796.7 & 292.1 \\
13 & 50.9 & 17.5 & 888.02406 & 2585.7 & 305.0 \\
14 & 42.7 & 17.4 & 743.900922 & 1824.5 & 303.3 \\
14 & 1012.5 & 241.2 & 17429.6049 & 104529.5 & 4159.1 \\
\hline
\end{tabular}


Tabel 3. Mencari nilai konstanta dan koefisien regresi

\begin{tabular}{llll}
\hline \multicolumn{1}{c}{$\boldsymbol{Y}^{2}$} & \multicolumn{1}{c}{$\boldsymbol{X}_{\boldsymbol{1}} \boldsymbol{X}_{2}$} & \multicolumn{1}{c}{$\boldsymbol{X}_{\boldsymbol{1}} \boldsymbol{Y}$} & \multicolumn{1}{c}{$\boldsymbol{X}_{2} \boldsymbol{Y}$} \\
\hline 2476911.7 & 1573.8 & 142451.2 & 27365.3 \\
276817.8 & 526.1 & 16052.4 & 9073.0 \\
3213315.6 & 1792.6 & 185950.7 & 30976.5 \\
974929.1 & 987.4 & 56233.5 & 17118.4 \\
530424.1 & 728.3 & 31108.7 & 12418.0 \\
846771.6 & 920.2 & 48664.0 & 16011.9 \\
8882804.4 & 2980.4 & 485936.9 & 54481.0 \\
8819648.3 & 2969.8 & 528895.7 & 49523.0 \\
209272.3 & 457.5 & 12096.2 & 7914.4 \\
124662.6 & 353.1 & 7181.6 & 6128.9 \\
2575242.3 & 1604.8 & 161759.4 & 25548.0 \\
816809.9 & 903.8 & 47795.3 & 15445.3 \\
788586.7 & 888.0 & 45156.0 & 15508.1 \\
553388.6 & 743.9 & 31775.0 & 12955.7 \\
31089584.9 & 17429.6 & 1801056.6 & 300467.6 \\
\hline
\end{tabular}

Tahap selanjutnya adalah mencari nilai dari parameter yang ada pada rumus pencarian $a, b_{1}$ dan $b_{2}$ dengan menggunakan rumus standar deviasi, berikut rumus dari standar deviasi

$$
\begin{aligned}
& \Sigma x_{1}^{2}=104,529.51 \frac{(1012.5)^{2}}{12}=31308 \\
& \Sigma x_{2}^{2}=4159.1-\frac{(241.21)^{2}}{12}=3.35556 \\
& \Sigma y^{2}=31089585-\frac{(17430)^{2}}{12}=9390219 \\
& \Sigma x_{1} y=1801057-\frac{(1012.5 \times 17430)}{12}=540556 \\
& \Sigma x_{2} y=300468-\frac{(241.21 \times 17430)}{12}=173.91 \\
& \Sigma x_{1} x_{2}=17430-\frac{(1012.5 \times 241.21)}{12}=-14.234
\end{aligned}
$$

Gambar 1 dibawah ini adalah bentuk implememntasi dari rumus pencarian standar deviasi diatas pada sistem:

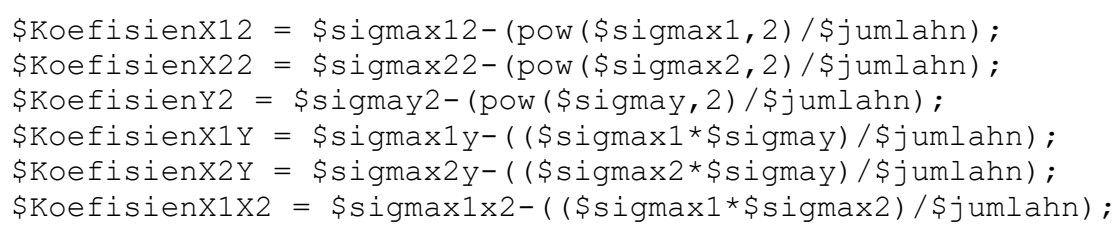

\section{Gambar 1. Implementasi Rumus Standar Deviasi Pada Sistem}

Kemudian setelah ditemukan nilai-nilai yang akan kita pakai pada rumus $a, b_{1}$ dan $b_{2}$. Kita masukan perhitungan standar deviasi tersebut ke dalam rumus:

$$
\begin{aligned}
& b^{1}=\frac{[(3.36 \times 540556)-(174 \times-14)]}{(31308 \times 3.36)-(-14)^{2}}=17.3227 \\
& b^{2}=\frac{[(31308 \times 174)-(540556 \times-14)]}{(31308 \times 3.36)-(-14)^{2}}=125.311 \\
& a=\frac{(\Sigma Y)-(17.323 \times 1012.5)-(125.3 \times 241.21)}{12}=-2166.78
\end{aligned}
$$


Gambar 2 dibawah ini adalah bentuk implememntasi dari rumus pencarian standar deviasi diatas pada sistem:

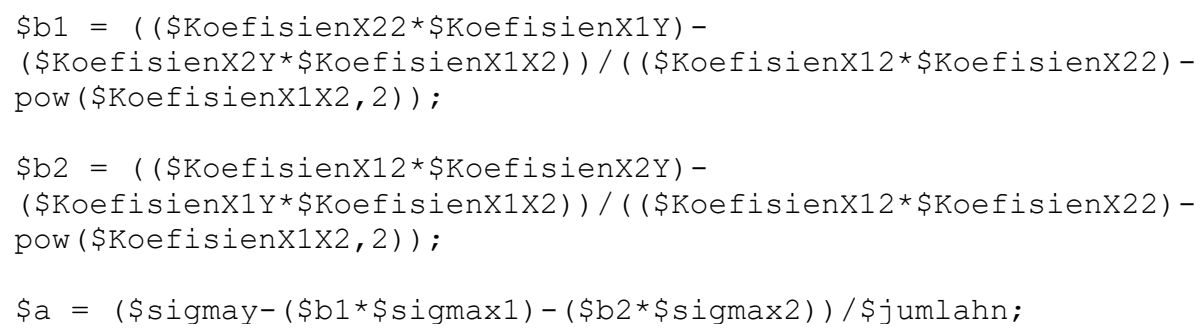

Gambar 2. Bentuk Implementasi Rumus Pencarian a, b1, b2 Pada Sistem

Dari perhitungan rumus standar deviasi dan juga pencarian nilai konstanta $a, b_{1}$ dan $b_{2}$, maka kita akan mendapatkan persamaan rumus regresi berganda seperti berikut ini:

$\mathrm{Y}=-2166.78+17.3227 * \mathrm{X}_{1}+125.3 .11 * \mathrm{X}_{2}$

Hasil dari persamaan diatas dapat dijelaskan seperti berikut:

1. Jika kita berasumsi bahwa nilai produksi $\left(\mathrm{X}_{1}\right)$ sama dengan 0 dan $\left(\mathrm{X}_{2}\right)$ sama dengan 0 , maka perusahaan akan rugi sebesar 2166.78

2. Jika jumlah produksi $\left(\mathrm{X}_{1}\right)$ bertambah 1 ton, maka keuntungan yang akan didapat yaitu sekitar 17.3277

3. Jika harga $\left(\mathrm{X}_{2}\right)$ naik sebesar 1 juta, maka keuntungan yang akan didapatkan oleh perusahaan dalam penjualan yaitu sekitar 125.311

\subsection{Memprediksi Penjualan Dengan Regresi Berganda}

Setelah mendapatkan nilai dari persamaan, memprediksi dapat dimulai dengan memasukan nilai $\mathrm{X}_{1}$ dan juga $\mathrm{X}_{2}$ pada persamaan berikut:

$\mathrm{Y}=-2166.78+17.3227 * \mathrm{X}_{1}+125.3 .11 * \mathrm{X}_{2}$

Dengan menggunakan persamaan rumus regresi berganda diatas, masukan nilai Produksi $\left(\mathrm{X}_{1}\right)$ sebesar 25ton dan juga harga $\left(\mathrm{X}_{2}\right)$ sebesar 30 juta kedalam persamaan persis seperti pada gambar 3 berikut:.

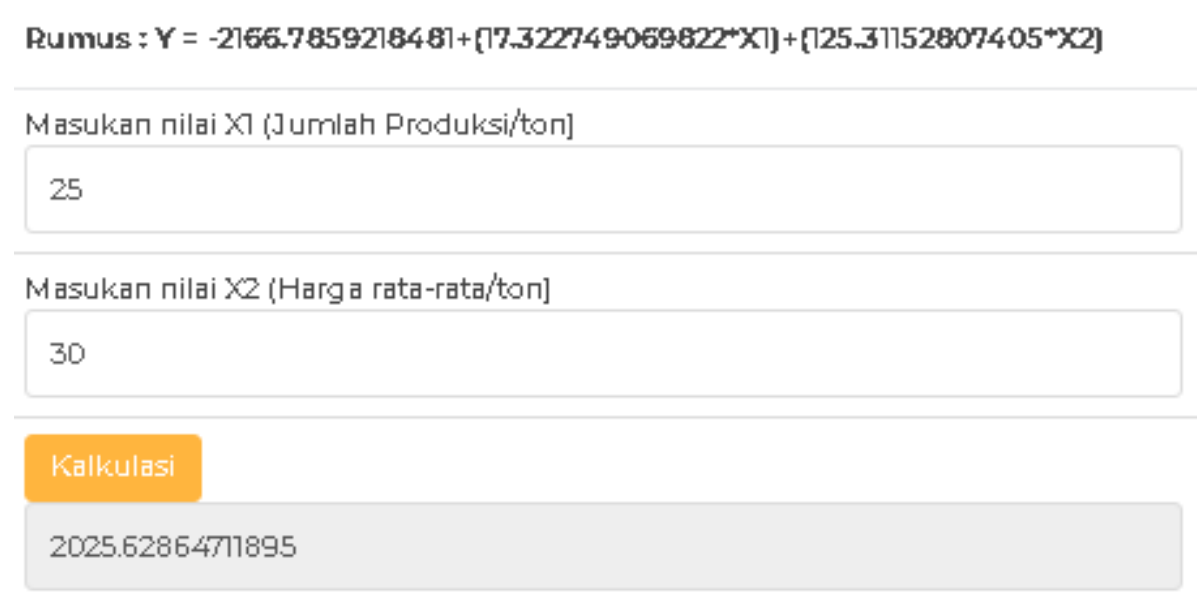

Gambar 3. Form Prediksi Regresi Berganda

Berikut adalah bentuk implementasi dari rumus regresi berganda pada sistem yang ditampilkan pada gambar 4. 


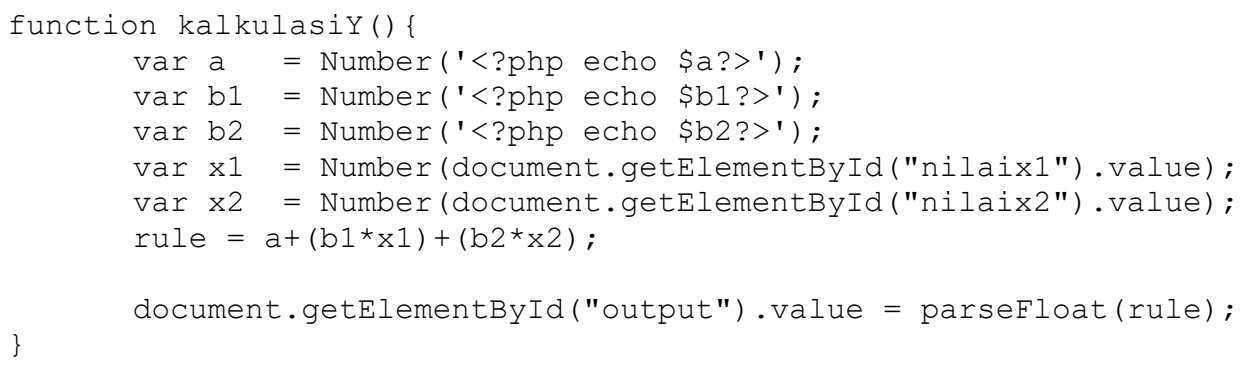

Gambar 4. Implementasi Rumus Regresi Berganda Pada Sistem

Dari gambar 3, dapat disimpulkan bahwa apabila perusahaan mampu memproduksi barang $\left(\mathrm{X}_{1}\right)$ dalam jumlah dua puluh lima ton, dan menjualnya dengan harga 30 juta, maka keuntungan yang didapatkan oleh perusahaan sebesar 2 milliar 25 juta enam ratus dua puluh delapan ribu.

\section{KESIMPULAN}

Berdasarkan apa yang telah penulis dapatkan dari implementasi metode regresi berganda atau multiple linear regression untuk memprediksi keuntungan, penulis menyimpulkan beberapa hal seperti berikut :

1) Dalam penerapan metode multiple linear regression, berdasarkan data penjualan perusahaan yang digunakan, dapat disimpulkan bahwa penjualan perusahaan akan untung sebesar 2025.628 atau apabila dibilangkan menjadi dua milliar dua puluh lima juta enam ratus dua puluh delapan ribu rupiah apabila perusahaan mampu memproduksi $\left(\mathrm{X}_{1}\right)$ barang dalam jumlah dua puluh lima ton dan menjual barang itu tiap ton nya dalam harga $\left(\mathrm{X}_{2}\right)$ tiga puluh juta

2) Hasil yang dikeluarkan oleh algoritma multiple linear regression pada program sudah cukup akurat mengingat penulis melakukan tes penggunaan metode pada program lain dan hasil yang dikeluarkan dapat disimpulkan bahwa tidak ada perbedaan sama sekali atau bisa disebut hasil yang dikeluarkan sudah akurat atau sudah sesuai dengan kaidah matematika regresi berganda

\section{DAFTAR PUSTAKA}

[1] Arisandy ambarita, "Analisis Pengembangan Sistem Informasi Pengolahan Aset Dearah (Studi Kasus: Dinas Pendapatan dan Pengelolaan Aset Daerah Provinsi Maluku Utara)," vol. 5, no. 4, pp. 47-56, 2018.

[2] Oktaviani.J, "Pengaruh Leverage Dan Pertumbuhan Aset Terhadap Nilai Perusahaan (Studi pada Perusahaan Manufaktur Sektor Aneka Industri yang Terdaftar di Bursa Efek Indonesia Tahun 2012-2016)," Sereal Untuk, vol. 51, no. 1, p. 51, 2018.

[3] S. Maulidiah, "Optimalisasi Pengelolaan Aset Sebagai Wujud Reformasi Birokrasi Di Daerah,” J. Pemerintahan, Polit. dan Birokrasi, vol. 3, no. 1, pp. 233-242, 2017.

[4] H. L. H. S. W. Aristo Putramasi Hintarsyah, Jessica Christy, "Forecasting Sebagai Decision Support Systems Aplikasi dan Penerapannya Untuk Mendukung Proses Pengambilan Keputusan.," J. Sist. Komput., vol. 8, no. 1, pp. 19-27, 2018.

[5] H. S. Hurint, I. Purnamasari, and M. N. Hayati, "Metode Regresi Robust Dengan Estimasi Method of Moment (Estimasi-MM) Pada Regresi Linier Berganda (Studi Kasus: Data Indeks Harga Konsumen (IHK) Provinsi Kalimantan Timur),”vol. 7, no. 2005, pp. 155-162, 2016.

[6] N. Marsha and I. Murtaqi, "The Effect of Financial Ratios on Firm Value in The Food and Beverage Sector of The IDX,”J. Bus. Manag., vol. 6, no. 2, pp. 214-226, 2017.

[7] I. L. L. Gaol, S. Sinurat, and E. R. Siagian, "Implementasi Data Mining Dengan Metode Regresi Linear Berganda Untuk Memprediksi Data Persediaan Buku Pada Pt. Yudhistira Ghalia Indonesia Area Sumatera Utara,” KOMIK (Konferensi Nas. Teknol. Inf. dan Komputer), vol. 3, no. 1, pp. 130-133, 2019.

[8] L. D. Damayanti, G. A. Yuniarta, and N. K. Sinarwati, “Analisis Pengaruh Kinerja Keuangan, Ukuran Komite Audit dan Kepemilikan Manajerial Terhadap Prediksi Financial Distress (Studi Pada Perusahaan Manufaktur Yang Terdaftar di Bursa Efek Indonesia Periode 2011-2015)," E-Journal Akunt., vol. 7, no. 1, pp. 1-12, 2017.

[9] E. Hartati, Y. Efendy, P. Studi, S. Informasi, and S. Palcomtech, "Pengukuran Tingkat Kepuasaan Pengguna Website Dengan Menggunakan Metode Analisis Regresi Berganda,” vol. 2, no. 1, pp. 28-29, 2016.

[10] D. Sari, O. Panggabean, E. Buulolo, and N. Silalahi, "Penerapan Data Mining Untuk Memprediksi Pemesanan Bibit Pohon Dengan Regresi Linear Berganda,” vol. 7, no. 1, pp. 56-62, 2020. 